Article

\title{
Economic Complexity and Ecological Footprint: Evidence from the Most Complex Economies in the World
}

\author{
Olimpia Neagu
}

Faculty of Economics, Computer Science and Engineering, "Vasile Goldiș” Western University of Arad, 310025 Arad, Romania; olimpia.neagu@uvvg.ro

Received: 25 August 2020; Accepted: 13 October 2020; Published: 30 October 2020

\begin{abstract}
The paper introduces economic complexity as an explanatory variable of ecological footprint change, along with income per capita and fossil fuel energy consumption. The link between the ecological footprint and economic complexity is explored within a panel of 48 complex economies over the period 1995-2014. The panel analysis is based on the annual data series of the economic complexity index (ECI), fossil fuel energy consumption, income per capita, and the ecological footprint of production. The econometrical analysis, based on second-generation unit root tests, cointegration testing, and estimation of fully modified ordinary square (FMOLS) and dynamic ordinary least square (DOLS) models in a heterogeneous panel of countries, revealed a validated positive long-run association between the ecological footprint of production as dependent variable and the economic complexity index, gross domestic product per capita, and fossil fuel energy consumption. The paper sheds light on the critical situation of environmental sustainability, taking into consideration that $75 \%$ of countries under examination are in ecological deficit.
\end{abstract}

Keywords: economic complexity; ecological footprint; panel data

\section{Introduction}

One of the major challenges for humanity in this century is to cope with the rising levels of environmental degradation and energy demand while keeping economic growth rates high. The relationship between economic activities, energy consumption, and environmental pollution has been thoroughly studied by different researchers (e.g., [1-22]), and an extensive and systematic review of such studies is provided by Vaheed et al. (2019) [23].

The main conclusion was that energy consumption, income, and $\mathrm{CO}_{2}$ or GHG emissions are evolving into a cointegrating relationship. Additionally, a significant part of the aforementioned studies was focused on providing evidence to support the environmental Kuznets curve (EKC) hypothesis (the inverted U-shaped relationship between air pollutant emissions and income). A great limitation of these studies was their focus on a singular or small group of air pollutants (mainly carbon dioxide, which is responsible for more than $76 \%$ greenhouse effect) as a proxy of environmental degradation [24]. The impact of economic activities on the environment has several dimensions that cannot be embedded within one measure of environmental degradation.

In the last few years, new literature that considers the ecological footprint (EF) as a comprehensive and globally comparable indicator of environmental degradation caused by human activities has emerged. It is viewed as a more accurate expression of environmental depreciation compared to carbon dioxide or GHG emissions, given that it tracks human demand for natural resources and ecosystem services (e.g., [25-31]). As a concise indicator of environmental pressure, the ecological footprint (EF) expresses the total quantity of natural resources that a population consumes [32] and measures the area of productive 
land and water necessary to support human activities and sequester the waste they generate [33]. In the methodology of the Global Footprint Network [34], biocapacity indicates the biologically productive land and water available to provide the resources a population consumes and to absorb its wastes. The ecological footprint generally refers to the EF of consumption, which expresses the consumption of biocapacity by a country's population. It comprises the ecological footprint of production and the net ecological footprint of trade. The ecological footprint of production measures the consumption of biocapacity resulting from production processes within a given area, and its carbon component indicates the amount of carbon emissions generated by the production process. The ecological footprint of imports and exports indicates the use of biocapacity within international trade [34].

Recent literature has revealed the impact of economic and social activities (i.e., industries, globalisation, agriculture, financial development, energy consumption, investment, trade, urbanisation, and human capital) on the ecological footprint by examining its determinants in different periods of time for groups or individual countries by using various econometric methods (e.g., [26,27,35-45]).

The economic growth of a country is sustained by a specific structure of the economy, requiring a given energy consumption structure according to specific demands from various economic sectors. Complex economies are those that can manage relevant knowledge across large networks of people to generate a diverse mix of knowledge-intensive products [46]. Economic complexity refers to a country's productive structure [46], which generates a specific economic and energy consumption structure that has a specific impact on the environment. Complex products are mainly the results of industrial manufacturing or chemical sectors, working with high levels of energy intensity. Higher complexity levels are generally associated with higher energy demand. In order to ensure the necessary energy and mitigate the environmental impact, countries must develop an appropriate energy mix from several sources (i.e., fossil fuel, nuclear, renewable), depending on their natural resources and import opportunities. Thus, it is obvious that a country's productive structure (i.e., with energy-intensive industrial and chemical sectors) will impact the environment; in other words, the complexity level of products can harm the environment by generating pollution and consuming natural resources [47,48]. It is also true that it embeds knowledge and capabilities (productive knowledge), research, and innovation, which can help to introduce environmentally friendly technologies to the production process and also plan the environmental impact of new complex products at the early design stage. The complexity of an economy is measured through the economic complexity index (ECI), calculated by the experts at the Centre of International Development at Harvard University [49]. It expresses the capability of a country to produce and export complex products and estimates the amount of productive knowledge embedded in that country. In other words, a higher level of ECI denotes a higher capability to produce and export higher value-added or more complex products [46].

The relationship between economic complexity and ecological footprint has not been analysed to date excepting in very few studies (i.e., [50-53]). The aim of the paper is to analyse the impact of economic complexity, per capita income, and energy consumption on the ecological footprint within a panel of 48 of the most complex economies in the world. From the global ranking of economic complexity index (ECI) [49], including 142 countries with ECI values in the range of -2.5 to 2.5, the first positions with ECI average value higher than 0 for 1995-2014 were extracted. It is resulted a sample of 48 complex economies, with complete data series for all considered variables. The study uses the most complex economies for several reasons. First, $75 \%$ of them are in ecological deficit (their ecological footprint exceeds the biocapacity area). The environmental quality concern raises the problem of identifying all the determinants of ecological degradation, and economic complexity could be included among them. The complexity level of products depends on the consumption of resources, which is related to ecological footprint. Second, these countries have some common features: similar economic structure (with large industrial sectors: machinery, chemical); a diversified energy mix, including renewable and nuclear energy; large public budgets for energy technology development and R\&D activities. Complex economies have extended industrial 
sectors that are energy, pollutant and knowledge-intensive. The Economic Complexity Index (ECI) captures information regarding institutions and governance, productive knowledge, human capital and economic competitiveness [46]. Economic complexity contributes to the environmental pressure but also, provides the required resources (i.e. institutions, knowledge, and competitiveness resources) to address the ecological deficit (i.e. the gap between biological capacity and ecological footprint). A high value of economic complexity index (ECI) indicates a high level of knowledge (embedded in people and technologies) and capabilities of an economy. These can also include its capacity to develop specific $R \& D$ activities meant to reduce environmental degradation. Economic complexity is positively associated with higher per capita income [46] suggesting the availability of funding resources for such $R \& D$ activities, investment in clean and energy-efficient technologies, development of alternative energy sources (i.e., renewable, nuclear) as well as for policy measures stimulating the transition to a low-carbon economy. Third, the quality of governance and institutions together with the competitive environment in complex economies would activate other factors (i.e., knowledge networks) meant to ensure an efficient use of resources (i.e., human, financial, knowledge, technologies).Therefore, the present analysis could serve as a case study for further research on environmental sustainability in developed countries and guidelines for other countries with similar pattern of economic structure.

There are several contributions of this study to the existing literature. First, it introduces the ecological footprint $(\mathrm{EF})$ as a variable of environmental quality in the analysis of the impact of economic complexity on the environment, along with other traditional factors (GDP per capita and energy consumption). Second, it analyses the impact of energy consumption on the ecological footprint of production. In this way, it addresses a critical aspect of the sustainable development of the most complex economies in the world and contributes to the literature of energy and environmental economics by taking as examples their energy policies and strategies. Third, the paper adds to the recent literature focused on the impact of economic complexity on the ecological footprint, with the aim of enriching it, given the very few studies in this field. It is different from existing studies through the extension of analysis from individual countries to a panel of countries, with similar levels of economic complexity, energy mix and policies, as well as efforts towards energy efficiency, decarbonisation, and investment in energy technology and innovation. This could outline a pattern of sustainability in the presence of high economic complexity that could be given as a basis for further research directions. Moreover, guidelines for countries with sophisticated products could be suggested. Fourth, to the best of the author's knowledge, this is the first attempt to test the impact of economic complexity on the ecological footprint in a panel of countries with the highest complex products. The countries included in the panel are in the top positions in the world for economic complexity. It is important to know how these countries use their energy mix to obtain a higher economic complexity and sustain their environmental quality. Some of them are leaders by example in decarbonisation and energy efficiency policies, as well as public budgets dedicated to R\&D activities and investments in clean energy technology. Fifth, the present study is different from similar studies (i.e., [48]) by using new econometrical methods for panel data (i.e., second-generation unit root and cointegration tests in the presence of cross-sectional dependence among the panel members) in order to demonstrate the cointegration between the considered variables (economic complexity index, GDP per capita, fossil fuel energy consumption).

The rest of the paper is organised as follows: Section 2 consists of a short review of the relevant literature, Section 3 presents the materials and methods used in the study, Section 4 exposes the empirical results, Section 5 provides a discussion of results and Section 6 contains the conclusions.

\section{Brief Literature Review}

Energy consumption has been identified as an augmenting factor for the ecological footprint, which threatens environmental sustainability [29,30,54-59]. Various forms of energy (fossil fuel, renewable, nuclear) have different impacts on the ecological footprint. Renewable energy has a positive contribution to environmental quality by decreasing the ecological footprint [60] while nonrenewable 
energy leads to an increase in the ecological footprint in the long- and short-run [37,61]. Similar results were revealed by Destek and Sinha (2020) [62] for OECD countries. It has also been demonstrated that hydroelectricity consumption can help to reduce the carbon footprint, water footprint and ecological footprint [63].

Energy consumption and economic growth are considered traditional determinants of the ecological footprint. Economic growth contributes to environmental degradation by leading to the extension of the ecological footprint [40,64-68]. Destek and Okumus (2019) [68] found that increased energy consumption and economic growth lead to an increase in the ecological footprint in newly industrialised countries for the period from 1982 to 2013. Similar results were obtained by Zafar et al. (2019) [69] for the US economy and by Usman et al. (2020) [70] for 33 upper- to middle-income countries from Asia, Africa, Europe and America.

A consistent part of the literature examining the determinants of the ecological footprint discusses the validity of the environmental Kuznets curve (EKC) hypothesis. Așici and Acar (2016) [45] confirmed the inverted U-shaped relationship between income and the ecological footprint of production for a panel of 116 countries from 2004 to 2008. Uddin et al. (2017) [44] illustrated a positive effect of real income on the ecological footprint in the 27 highest-emitting countries. In Wang and Dong's study (2019) [71], similar results were obtained for a panel of 14 sub-Saharian African countries. Destek and Sarkodie (2019) [39] confirmed the validity of the EKC hypothesis on 11 newly industrialised countries. The EKC hypothesis is also confirmed for 17 countries in Africa by Sarkodie (2018) [72]. Uddin et al. (2019) [73] provided evidence in support of the EKC hypothesis in some Asian countries, with Destek et al. (2018) [26] doing the same for the EU countries.

As an expression of a country's knowledge level and skills needed in the production of the exported goods, economic complexity has been included by several authors as a factor in pollution (i.e., $[47,48,74-76])$. More recently, some studies have explored the role of economic complexity for environmental quality, expressed through the ecological footprint. An example is the study of Swart and Brinkman (2020) [50], who found that economic complexity is associated with decreasing environmental degradation in Brazil. Yilanci and Pata (2020) [51] analysed the short- and long-term relationship between economic growth, economic complexity, energy consumption and ecological footprint in China over the period 1965-2016. Their results illustrated that economic complexity, energy consumption and economic growth have led to the extension of the ecological footprint in China. Pata (2020) [52] found that an inverted U-shaped EKC relationship between economic complexity and the ecological footprint is valid in the USA for the period 1980-2016. The US economy was also investigated by Shahzad et al. (2021) [53], who confirmed that economic complexity and fossil fuel energy consumption raised the ecological footprint.

\section{Materials and Methods}

\subsection{Model and Data}

The study uses the following econometrical model:

$$
\mathrm{EF}=\mathrm{f}(G D P p c, F F C, E C I)
$$

where $E F$ denotes the ecological footprint, GDPpc is Gross Domestic Product per capita, FFC represents the share of fossil fuel in the total energy consumption and $E C I$ is the economic complexity index.

Ecological footprint $(E F)$ represents a method of ecological economics expressing the consumption of natural resources and waste generation. According to the methodology developed by the Global Footprint Network [34], it is measured in global hectares (biologically productive hectares with world average biological productivity for a given year).

The economic complexity index $(E C I)$ reflects a country's productive structure through a combination of diversity (number of exported products) and ubiquity (the number of countries that export that product [77]. 
For the purpose of the study, a panel of 48 countries with a positive average value of economic complexity index (ECI) for 1995-2014 and with complete data series for all other variables under examination were selected: Japan, Switzerland, Germany, South Korea, Singapore, Czech Republic, Sweden, Austria, USA, Hungary, Finland, Slovenia, United Kingdom, Italy, France, Slovenia, Slovakia, Mexico, Ireland, Denmark, The Netherlands, Israel, Spain, Poland, Brazil, Portugal, Norway, New Zealand, Canada, Estonia, Latvia, Lithuania, Croatia, Bulgaria, Romania, Belarus, Russia, Australia, Malaysia, Thailand, Greece, India, Turkey, South Africa, Saudi Arabia, Uruguay and Colombia (please see Appendix A). The ECI data series were retrieved from the Atlas of Economic Complexity [49].

The data set for the ecological footprint of production (in global hectares per capita) was extracted from the Global Footprint Network [34], whereas data for fossil fuel energy consumption (as \% of total final consumption), as well as gross domestic product (GDP) per capita (PPP; constant 2017 international dollars), come from the World Development database [78].

We translate the econometrical model (1) in the following regression equation, namely, Equation (2):

$$
\ln E F P_{i t}=\alpha_{i}+\beta_{1 i t} \cdot E C I+\beta_{2 i t} \cdot F F C+\beta_{3 i t} \cdot R E+\beta_{4 i t} \cdot \ln G D P p c_{i t}+\mu_{i t}
$$

where $i$ denotes the country, respectively; $\mathrm{t}$ denotes the time; EFP is the ecological footprint of production per capita; GDPpc means the gross domestic product per capita; FFC is the share of fossil fuel in the total energy consumption; $E C I$ is the economic complexity index; $\beta_{1}, \beta_{2}, \beta_{3}, \beta_{4}$ are regression coefficients; $\alpha$ is the intercept (a scalar); $\mu_{i t}$ is the error term.

\subsection{Econometric Approach}

Within the paper's methodology, the following steps are taken: (i) checking the cross-sectional dependence among variables; (ii) testing the variables' stationarity (the presence of unit root); (iii) if the data series at a level have a unit root and the stationarity is found for the I(1) level series, their cointegration relationship is checked; (iv) if the cointegration relationship between variables is identified, coefficients of the fully modified ordinary square (FMOLS) and dynamic ordinary least square (DOLS) regression models are estimated.

\subsubsection{Cross-Sectional Dependence}

In order to check the cross-sectional dependence among variables, we use the Pesaran (2004) [79] $\mathrm{CD}$ test. The null hypothesis of no cross-sectional dependence, the correlation of disturbances between different cross-sections, is zero: $H_{0}: \rho_{i j}=\operatorname{corr}\left(u_{i t}, u_{j t}\right)=0$, for $i \neq j$, while the alternative hypothesis states that it exists, namely, $i \neq j$, making $\rho_{i j}=\operatorname{corr}\left(u_{i t}, u_{j t}\right) \neq 0$ The test statistic is given by Formula (3):

$$
C D=\sqrt{\frac{2}{N(N-1)}}\left(\sum_{i=1}^{N-1} \sum_{j=i+1}^{N} T_{i j} \hat{\rho}_{i j} \rightarrow N(0,1)\right)
$$

where $\hat{\rho}_{i j}$ denotes the correlation coefficients obtained from the residuals; $\mathrm{N}$ and $\mathrm{T}$ denote the countries and the years of observation, respectively.

The null hypothesis of no cross-sectional dependence is rejected when the values of Prob. are under 0.05 .

\subsubsection{Stationarity of Variables}

As Phillips and Sul (2003) [80] have indicated, the efficiency of the estimated results may decrease when cross-serial correlation across sections in the panel is identified. In order to ensure accurate and reliable results, given the presence of cross-sectional dependence, we apply two types of second-generation unit root tests proposed by Pesaran (2007) [81]: the cross-sectional ADF 
(PES-CADF) and the cross-sectional augmented IPS (CIPS). These tests take into account the existence of cross-sectional dependence generated by unknown common factors affecting the panel sections.

Pesaran (2007) [81] introduced the cross-sectionally augmented Dickey-Fuller (CADF) test, consisting of standard Dickey-Fuller (DF) regressions augmented with cross-sectional averages of lagged levels and the first difference series of the $i$-th cross-section in the panel:

$$
\Delta y_{i t}=\alpha_{i}+\rho_{i} y_{i, t-1}+\delta_{i} y_{t-1}+\sum_{j=0}^{k} \delta_{i j} \Delta y_{i, t-j}+\sum_{j=0}^{k} \Delta y_{i, t-j}+\varepsilon_{i t}
$$

where $y_{t-1}=\frac{1}{N} \sum_{i=1}^{N} y_{i, t-1} ; \Delta y_{t}=\frac{1}{N} \sum_{i=1}^{N} y_{i t} ; \alpha_{i}$ is constant; $\mathrm{k}$ is the lag specification; $t_{i}(N, T)$ is the $t$-statistic of the estimated $\rho_{i}$ in the above equation, computed in individual ADF statistics.

CIPS is the average of individual CADF statistic values for individual cross-sections:

$$
\text { CIPS }=\frac{1}{N} \sum_{i=1}^{N} t_{i}(N, T)
$$

where $t_{i}(N, T)$ is the CADF statistic for the $i$-th cross-section unit given by $\rho_{i}$ in the CADF regression.

In both tests, under the null hypothesis of homogeneous unit root, all sections in the panel are nonstationary, while the alternative states that at least one individual section in the panel is stationary.

Application of these second-generation unit root tests is common in several studies that focus on the link between pollution, economic growth and energy consumption. For example, Eggoh et al. (2011) [82] used them in support of evidence regarding the relationship between energy consumption and economic growth for 21 African countries. Dogan and Seker (2016) [83] employed them with respect to carbon emissions, real growth, and energy consumption; Asafu-Adjaye et al. (2016) [84] and Dogan and Aslan (2017) [85] applied them with regard to carbon emissions, energy use and economic growth in the EU and other candidate countries. Jardon et al. (2017) [86] employed such tests for Latin America and Caribbean countries to analyse the link between carbon emissions and economic growth, while Mensah et al. (2019) [87] used them in a panel of 22 African countries for the relationship between carbon emissions, economic growth, fossil fuel energy consumption and oil price. Destek and Sinha (2020) [62] also used these tests in their study examining the validity of the environmental Kuznets curve hypothesis in 24 OECD countries.

\subsubsection{Panel Cointegration Tests}

According to Engle and Granger (1987) [88], a combination of two or more nonstationary series may be stationary, meaning that they are cointegrated. This linear combination reflects the long-run relationship between variables. In the Engle-Granger cointegration test, the residuals of a regression performed using I(1) variables are examined. When the variables are cointegrated, then the residuals should be I(0). In our case, if the considered variables are not stationary at their level value, but integrated in their first order (I(1)), we check the cointegration relationship between them through the Pedroni test $(1999,2004)[89,90]$. This test is based on Engle-Granger two-step (residual-based) cointegration tests for heterogeneous panel data. It allows for heterogeneous intercepts and trend coefficients of the cointegration equation across cross-sections and assumes the cross-sectional dependence. It involves the computation of seven statistics (ingroup and intergroup statistics). If at least four values of Prob. corresponding to these statistics are under the selected significance level ( $1 \%$ or $5 \%)$, the null hypothesis of no cointegration for all $i$ is rejected, indicating a long-term relationship between the considered variables.

In addition, to ensure the robustness and accuracy of results in the presence of cross-sectional dependence, the Westerlund (2005) [91] cointegration test will be also applied. The test is computed using the alternative hypothesis that some of the panels are cointegrated, based on the group-mean 
variance-ratio (VR) statistic, testing for no cointegration by testing the presence of a unit root in the residuals. The test uses two assumptions: cointegration of variables is present in some of the panels or in all the panels. Under the first assumption, the AR parameter is panel-specific, and the alternative hypothesis is that the series in some panels are cointegrated. Under the second option (all panels are cointegrated), the AR parameter is the same over the panels. The $p$-value of the VR statistic indicates the rejection/acceptance of the null hypothesis of no cointegration. When this value is less than the chosen significance level, the null hypothesis of no cointegration is rejected in favour of the alternative that at least some panels or all panels are cointegrated.

\subsubsection{Estimation of Long-Run Relationship Through FMOLS and DOLS Models}

We estimate the regression equations (2) and (3) by using the panel fully modified ordinary square (FMOLS) and the panel dynamic ordinary least square (DOLS) models developed by Pedroni [92,93].

The panel FMOLS equation is specified below as Equation (6).

$$
\begin{gathered}
y_{i t}=\alpha_{i t}+\delta_{i t} t+\beta x_{i t}+\mu_{i t} \\
x_{i t}=x_{i t-1}+e_{i}
\end{gathered}
$$

where $y_{i t}$ is the dependent variable; $x_{i t}$ is the independent variable; $\alpha_{i t}$ denotes the constant effects; $\beta$ is the estimated long-term cointegration coefficient/vector.

The panel FMOLS estimator for the $i$-th section in the panel is computed according to Formula (8) below:

$$
\hat{\beta}_{F M}^{*}=n^{-1} \sum_{i=1}^{n} \hat{\beta}_{F M, i}^{*}
$$

The cointegration coefficient for the overall panel is computed by using the mean value of FMOLS coefficients in the cross-sections.

The $t$-statistic for the panel cointegration coefficient $\left(t_{\wedge *}^{*}\right)$ is computed through Formula (9) below:

$$
\beta_{F M}
$$

$$
t_{\beta_{F M}^{*}}^{*}=n^{-1} \sum_{i=1}^{n} t_{\beta_{F M, i}}
$$

Within the panel DOLS method, the following Equation (10) is used:

$$
y_{i t}=\alpha_{i}+\beta_{i} x_{i t}+\sum_{k=-K_{i}}^{K_{i}} \gamma_{i t} \Delta x_{i t-K}+\varepsilon_{i t}
$$

The estimation of Equation (10) is first made for each cross-section of the panel, and then the overall panel cointegration coefficient is computed as the average value of the DOLS coefficients in the cross-sections.

The panel DOLS estimator is calculated with Formula (11) below:

$$
\hat{\beta_{D}}=n^{-1} \sum_{i=1}^{n} \hat{\beta}_{D, i}
$$

Finally, the $t$-statistic for the panel cointegration coefficient is given by Formula (12):

$$
t_{\beta_{D}}^{*}=n^{-1} \sum_{i=1}^{n} t_{\beta_{\text {* }}}^{n}
$$




\section{Results}

\subsection{Descriptive Statistics of Variables}

The descriptive statistics of the variables under examination are displayed in Table 1.

Table 1. Descriptive statistics of variables.

\begin{tabular}{cccccccc}
\hline Variable & Mean & Median & Maximum & Minimum & $\begin{array}{c}\text { Standard } \\
\text { Deviation }\end{array}$ & Skewness & Kurtosis \\
\hline $\begin{array}{c}\text { Ecological Footprint of } \\
\text { production (lnEFP) }\end{array}$ & 1.524169 & 1.464386 & 2.669424 & -0.240926 & 0.532601 & -0.097331 & 3.900412 \\
$\begin{array}{c}\text { Economic Complexity } \\
\text { Index (ECI) }\end{array}$ & 0.910613 & 0.831334 & 2.463821 & -0.398851 & 0.614959 & 0.373760 & 2.204241 \\
$\begin{array}{c}\text { Fossil fuel Consumption } \\
\quad(\text { InFFC) }\end{array}$ & 4.317339 & 4.397530 & 4.605138 & 2.673479 & 0.270459 & -2.101228 & -0.885131 \\
$\begin{array}{c}\text { Gross Domestic Product } \\
\text { per Capita (lnGDPpc) } \\
\text { Observations }\end{array}$ & 10.15539 & 10.28386 & 11.38292 & 7.64995 & 0.629779 & -0.885131 & 3.995018 \\
\hline & 960 & 960 & 960 & 960 & 960 & 960 & 960 \\
\hline
\end{tabular}

Table 2 exhibits the correlation coefficients between the explanatory variables. We noticed the value of 0.6261 , illustrating a strong positive correlation between gross domestic product per capita $(\ln G D P p c)$ and the economic complexity index $(E C I)$.

Table 2. Correlation matrix of independent variables.

\begin{tabular}{cccc}
\hline & $\begin{array}{c}\text { Economic } \\
\text { Complexity Index } \\
(E C I)\end{array}$ & $\begin{array}{c}\text { Fossil Fuel } \\
\text { Consumption } \\
(\ln F F C)\end{array}$ & $\begin{array}{c}\text { Gross Domestic } \\
\text { Product per Capita } \\
\text { (lnGDPpc) }\end{array}$ \\
\hline Economic Complexity index $(E C I)$ & 1 & -0.1264 & 0.6261 \\
Fossil Fuel Consumption (lnFFC) & -0.1264 & 1 & -0.0166 \\
Gross Domestic Product per & 0.6261 & -0.0166 & 1 \\
$\quad$ Capita (lnGDPpc) & & & \\
\hline
\end{tabular}

In order to test the multicollinearity of independent variables, we used the variance inflation factor (VIF) algorithm. The VIF values are exposed in Table 3. For all variables FIV has values less than 4 , indicating the absence of multicollinearity.

Table 3. Multicollinearity test.

\begin{tabular}{ccc}
\hline & \multicolumn{2}{c}{ Variance Inflation Factors (VIF) (Uncentered) } \\
\hline Variable & FMOLS Model & DOLS Model \\
\hline Economic Complexity Index $(E C I)$ & 1.2821 & 1.3026 \\
Fossil Fuel Consumption $(\ln F F C)$ & 1.0457 & 1.0487 \\
Gross Domestic Product per Capita $(\ln G D P p c)$ & 1.3269 & 1.3526 \\
\hline
\end{tabular}

\subsection{Cross-Sectional Dependence Test}

Table 4 depicts the results of the cross-sectional dependence check for all variables by using the Pesaran CD test. The probability values for the CD test of all variables are significant at the $1 \%$ level, indicating the rejection of the null hypothesis of cross-sectional independence. This result is important to the next methodological step, namely, the stationarity of variables by applying second-generation panel unit root tests that account for cross-sectional dependence. 
Table 4. Results of the cross-sectional dependence test.

\begin{tabular}{ccccc}
\hline & $\begin{array}{c}\text { Ecological Footprint } \\
\text { of Production (lnEFP) }\end{array}$ & $\begin{array}{c}\text { Economic } \\
\text { Complexity Index } \\
(E C I)\end{array}$ & $\begin{array}{c}\text { Fossil Fuel } \\
\text { Consumption } \\
(\ln F F C)\end{array}$ & $\begin{array}{c}\text { Gross Domestic } \\
\text { Product per Capita } \\
(\ln G D P p c)\end{array}$ \\
\hline $\begin{array}{c}\text { CD statistic } \\
p \text {-value }\end{array}$ & 14.059 & 5.771 & 28.509 & 126.734 \\
\hline
\end{tabular}

\subsection{Data Stationarity}

As aforementioned, we checked the presence of unit root by using the second-generation unit root tests, as suggested by Pesaran (2007) [87], PES-CADF and CIPS. Results from these panel unit tests are robust in the presence of heterogeneity and cross-sectional dependence and are reported in Table 5. Both tests show that the null hypothesis of the nonstationarity of variables at their level value cannot be rejected, but a stationary process is identified in their first difference series.

Table 5. Results of the second-generation unit root tests.

\begin{tabular}{ccccc}
\hline \multirow{2}{*}{ Variable } & \multicolumn{2}{c}{ PES-CADF Test } & \multicolumn{2}{c}{ CIPS Test } \\
\cline { 2 - 5 } & Constant & $\begin{array}{c}\mathrm{z}(t \text {-Bar) } \\
\text { Constant and Trend }\end{array}$ & No Constant & $\begin{array}{c}\text { Constant and Trend } \\
\text { Constic }\end{array}$ \\
\hline $\ln E F P$ & 1.879 & $-2.531^{* * *}$ & -1.191 & $-2.659^{* *}$ \\
$E C I$ & $-4.622^{* * *}$ & 0.855 & -1.003 & -2.251 \\
$\ln F F C$ & $-1.112^{* * *}$ & -0.760 & -1.469 & $-2.603^{*}$ \\
$\ln G D P p c$ & $-5.158^{* * *}$ & -0.936 & -0.185 & $-1.681^{* * *}$ \\
$\Delta \ln E F P$ & $-7.037^{* * *}$ & $-5.635^{* * *}$ & $-4.470^{* * *}$ & $-4.949^{* * *}$ \\
$\Delta E C I$ & $-7.140^{* * *}$ & $-4.242^{* * *}$ & $-3.791^{* * *}$ & $-3.774^{* * *}$ \\
$\Delta \ln F F C$ & $-10.801^{* * *}$ & $-8.387^{* * *}$ & $-4.016^{* * *}$ & $-4.255^{* * *}$ \\
$\Delta \ln G D P p c$ & $-2.985^{* * *}$ & $-4.595^{* * *}$ & $-2.617^{* * *}$ & $-2.960^{* * *}$ \\
\hline
\end{tabular}

\subsection{Panel Cointegration Test}

When established that the variables were integrated by first order I(1), the residual Pedroni and Westerlund cointegration tests were performed. The results of Pedroni cointegration test show that in five cases out of 11, the value of Prob. is under 5\% for the variables of each equation Equation (2), as shown in Table 6. This leads us to the conclusion that the cointegration relationship between $\ln E F P$, $E C I, \ln F F C$ and $\ln G D P p c$ is identified.

Table 6. Results of the Pedroni residual cointegration test.

\begin{tabular}{cccccc}
\hline \multicolumn{6}{c}{ Variables: Ecological Footprint of Production, Economic Complexity, Fossil Fuel Consumption, } \\
Renewable Energy, Gross Domestic Product Per Capita \\
\hline Test & Statistic & Prob. & Statistic & Prob. & \\
\hline Panel v-statistic & 0.6844 & 0.2468 & 0.913678 & 0.1804 & common AR \\
Panel rho-statistic & 1.753668 & 0.9603 & 1.301084 & 0.9034 & coefficients \\
Panel PP-statistic & -1.496151 & 0.0673 & -2.571833 & 0.0051 & (within-dimension) \\
Panel ADF-statistic & -3.555778 & 0.0002 & -5.076073 & 0.0000 & \\
\hline Panel rho-statistic & 4.011549 & 1.000 & & & individual AR \\
Panel PP-statistic & -2.098280 & 0.0179 & & & coefficients \\
Panel ADF-statistic & -6.167930 & 0.0000 & & &
\end{tabular}

Table 7 depicts the results of the Westerlund cointegration test. We noticed that the values of Prob. for both assumptions (some panels are cointegrated and all panels are cointegrated) are less than 0.01 . This suggests the rejection of the null hypothesis of no cointegration between $\ln E F P, E C I, \ln F F C$, $\ln G D P p c$ for a significance level of $1 \%$ under both assumptions. 
Table 7. Results of the Westerlund (2005) cointegration test.

\begin{tabular}{lccc}
\hline \multicolumn{4}{c}{ Assumptions } \\
\hline "Some Panels are Cointegrated" & "All Panels are Cointegrated" \\
\hline Statistic & $p$-Value & Statistic & $p$-Value \\
-2.8941 & 0.0019 & -3.3311 & 0.0004 \\
\hline
\end{tabular}

\subsection{Estimation of Long-Run Parameters}

Given the identified cointegration relationship through both tests (Pedroni and Westerlund), we further estimated the FMOLS and DOLS equations. We estimated their coefficients in several stages by starting with the traditional determinants of the ecological footprint and adding them one by one: GDP per capita, fossil fuel energy consumption and lastly, we added our variable of interest, economic complexity.

The estimation of the FMOLS and DOLS models shows that ECI, $\ln F F C$ and $\ln G D P p c$ have a positive and validated influence on the ecological footprint of production. The estimated coefficients of the FMOLS equation show that for a $1 \%$ increase of $E C I$, the ecological footprint of production (in ln of global hectares per capita) will rise by 0.0734 percentage points for $5 \%$ level of significance. When $\ln F F C$ increases with $1 \%$, the ecological footprint of production will extend by 0.2292 , for $5 \%$ level of significance, respectively, when the growth of $\ln G D P p c$ is $1 \%$, the growth in the ecological footprint of production is of 0.1756 percentage points, for $1 \%$ significance level. The estimated coefficients of the DOLS model are validated for $1 \%$ significance level. An increase of $1 \%$ of $E C I$ would lead to an increase of 0.0534 percentage points of ecological footprint of production. Respectively, if $\ln F F C$ rises with $1 \%$, the augmentation of ecological footprint of production is of 0.2201 percentage points. The $1 \%$ increase of $\ln G D P p c$ would generate an extension of 0.2539 percentage points of ecological footprint of production (Table 8).

Table 8. Estimation of coefficients of the fully modified ordinary square (FMOLS) and dynamic ordinary least square (DOLS) models.

\begin{tabular}{|c|c|c|c|c|c|c|}
\hline \multicolumn{7}{|c|}{ Dependent Variable: Ecological Footprint of Production $(\ln E F P)$} \\
\hline & \multicolumn{3}{|c|}{ FMOLS } & \multicolumn{3}{|c|}{ DOLS } \\
\hline & $\begin{array}{c}\text { Gross } \\
\text { Domestic } \\
\text { Product per } \\
\text { Capita } \\
(\ln G D P p c)\end{array}$ & $\begin{array}{l}\text { Fossil Fuel } \\
\text { Consumption } \\
\quad(\ln F F C)\end{array}$ & $\begin{array}{c}\text { Economic } \\
\text { Complexity } \\
\text { Index }(E C I)\end{array}$ & $\begin{array}{c}\text { Gross } \\
\text { Domestic } \\
\text { Product per } \\
\text { Capita } \\
(\ln G D P p c)\end{array}$ & $\begin{array}{l}\text { Fossil Fuel } \\
\text { Consumption } \\
\quad(\ln F F C)\end{array}$ & $\begin{array}{l}\text { Economic } \\
\text { Complexity } \\
\text { Index }(E C I)\end{array}$ \\
\hline \multirow{3}{*}{ Coefficients } & $0.1960 * *$ & & & $0.2018 * *$ & & \\
\hline & $0.2126 * *$ & $0.2322 *$ & & $0.2359 * *$ & $0.3877 * *$ & \\
\hline & $0.1756^{* *}$ & $0.2292 *$ & 0.0734 * & $0.2539 * *$ & $0.2201 * *$ & $0.0534^{* *}$ \\
\hline R-squared & 0.9353 & 0.9393 & 0.9304 & 0.9504 & 0.9544 & 0.9737 \\
\hline Observations & 960 & 960 & 960 & 960 & 960 & 960 \\
\hline Cross-sections & 48 & 48 & 48 & 48 & 48 & 48 \\
\hline
\end{tabular}

\section{Discussion}

The econometrical analysis performed in the present study concluded that an increase of economic complexity in the 48 most complex economies in the world leads to an extension of the ecological footprint in production, contributing in this way to the ecological deficit of these countries. As expected, energy consumption based on fossil fuel and income (GDP per capita) also has an extension effect on the ecological footprint in production. This paper's findings suggest that economic complexity 
should be seen as a threat of environmental quality. It also must be mentioned that three quarters of the countries under examination are in ecological deficit, which raises the question of how to ensure environmental sustainability given their economic complexity development. More complex and sophisticated products require an increased energy demand that can be covered through an appropriate energy mix, generating less pollution.

The influence of fossil fuel energy consumption on the ecological footprint of production is still positive in these complex economies. The continued usage of fossil fuel will be detrimental to environmental quality. Therefore, to ensure sustainable development, the share of renewable sources in the energy mix should be extended along with strategies for decarbonisation and large investments in R\&D for energy technology development. Based on World Bank data (2020) [78] an increasing share of renewable energy consumption is noticed in 34 of the 48 examined countries. The highest shares of renewable resources in the energy mix at the end of the examined period of time (2014) are registered in Norway (57.1\%), Sweden (49.9\%), Finland (43.3\%), Latvia (40.2\%), Austria (35.3\%), Croatia (33.6\%) and Denmark (33.2\%), while the lowest are in Saudi Arabia (0.005\%), Singapore (0.62\%), Israel $(2.8 \%)$, South Korea (2.8\%), Ukraine (3.4\%) and Russia (4.2\%).

Embedding productive knowledge and a high quality human capital, complex economies posses the potential to stimulate the application of clean technologies and plan the environmental impact of a product at its design stage. This would also stimulate research that is oriented to find and discuss how more complex products (embedding more sophisticated human and technological capabilities) could contribute not only to economic prosperity (as already demonstrated in [77,94-97]), but also to increase environmental quality or, at least, maintain it.

Although the present study did not look at the situation when the variable of interest (economic complexity) is squared (the environmental Kuznets curve hypothesis), a decline in environmental deterioration can be expected when economic complexity will grow. This is based on previous studies revealing this quadratic dependency for the EU countries with high economic complexity (e.g., [47,98]). This suggests that starting from a certain level of economic complexity the environmental degradation could decrease. Recent studies are providing evidence in supporting the idea that reduction of the pressure on environment could come from economic complexity. For example, Dong et al. (2020) [99] found that more complex industrial structure is related to less coal consumption in China, suggesting that policies targeted on emission reduction can improve the performance of an industry with very high complexity. Based on a study examining 67 countries for 1976-2012, Romero and Gramkov (2020) [100] found that the production of complex goods is associated with lower emission intensity. This is the result of various types of production technologies and the high value-added of complex products [100].

The examined countries have a specific energy mix that can provide the required energy resources, as volume and structure, for their sophisticated production. Their export baskets include complex products made in pollutant industrial sectors (chemical, agriculture, machinery). Machinery, vehicles parts are mainly included in the export basket of USA, France, Germany, Japan, Thailand, Turkey, Portugal and the Czech Republic; chemicals and electronics in Israel, Singapore, Ireland and Finland; chemical and agricultural products in The Netherlands and Denmark; chemical and machinery in the UK, Austria, Slovenia, France, Hungary and Italy; vehicles and electronics in Mexico; machinery and electronics in South Korea; refined and crude petroleum in Estonia, Canada, Malaysia, Saudi Arabia, Lithuania, Norway, Belarus, Latvia, Croatia, Ukraine, Bulgaria, Colombia, India and Greece; vehicles, machinery and agricultural products in Poland, Spain and Sweden; chemicals and jewellery in Switzerland; gold and diamonds in South Africa; packed medicaments in Lithuania, Latvia, Croatia, Greece and Bulgaria; food products in Brazil, New Zealand, Uruguay Argentina and India [49].

As Member States of the United Nations, these countries assumed the 2030 Sustainable Development Goals (SDGs). Therefore, we can believe that they are focusing on a coherent policy to obtain synergy between economic, social and environmental dimensions of sustainability. However, the ascending trend of the ecological footprint in countries like Austria, Singapore, Israel, Hungary, 
Slovenia and Slovakia should be of great concern and placed at the core of their environmental and energy policies.

Complex economies are prosperous and higher levels of ECI indicate a certain quality of governance, a large basis of knowledge (embedded in individuals and technologies) and high economic competitiveness [46]. Thus, the countries under examination have all resources they need and the appropriate potential to make progress toward reducing pressure on ecological capacity. This concern is not just a part of their commitment for achieving the Sustainable Development Goals (SDGs) but also, an awareness of the Intergovernmental Panel of Climate Change (IPPC) report on "climate change, desertification, land degradation, sustainable land management, food security and greenhouse gas fluxes in terrestrial ecosystems" [101].

The above considerations suggest a pattern of environmental sustainability concern derived from common features of the examined countries [102]: (i) investment in energy technology development; (ii) a diversified energy mix, including renewable and nuclear energy, taking into account safety, energy security, economic efficiency and environmental protection; (iii) increase in low-carbon sources of primary energy and electricity supply through fiscal incentives and requirements for energy efficiency and promotion of potential for innovation in critical low-carbon technologies; (iv) implementing electricity and gas market reforms; (v) fostering renewable energy deployment through consumer tariffs, advancement in new technologies and institutional arrangements to accelerate grid integration.

\section{Conclusions}

The paper intends to highlight the link between the ecological footprint of production and economic complexity by taking into consideration other factors influencing the environment, namely, income per capita and fossil fuel energy consumption, in 48 of the most complex economies in the world over the period 1995-2014. Second-generation unit root tests and cointegration tests, accounting for cross-sectional dependence and heterogeneity of panel data, were employed to examine the long-run relationship between the considered variables.

A stable long-run relationship is revealed between the ecological footprint of production and economic complexity, fossil fuel energy consumption and per capita income. It is found that economic complexity leads to an extension in the ecological footprint generated by production activities. This result is in line with other studies highlighting economic complexity as an additional determinant of ecological footprint extension (i.e., [50-53]). The present study extends the analysis from individual countries (i.e. the USA, China, Brazil) to a panel of countries with higher economic complexity by using a heterogeneous panel data approach with second-generation tests. The experience of complex economies in producing and exporting sophisticated goods, their specific economic structure (with large industrial and chemical sectors) and investment in clean and energy-efficient industrial technologies could serve as guidelines for other countries on how to find the balance between a high level of complexity and environmental quality.

The main conclusion of the study refers to the negative impact of economic complexity, along with other factors (fossil fuel energy consumption, income), on environmental quality, expressed by the ecological footprint. This paper uses this popular indicator of human impact on environmental resources, the ecological footprint, to emphasise that its rise due to the economic complexity of products will add to the ecological deficit in the countries under examination.

Given the revealed impact of economic complexity on environmental quality in the examined countries, national environmental policies should include, in addition to incentives for technological innovation (i.e., cleaner technologies in exports, environmentally friendly production processes, smart grids), specific goals dedicated to reducing the effect of economic complexity on the environment. Thus, the paper's findings suggest more targeted national actions, meant to place the economy on a path leading to sustainability, as policy implications.

As further directions of research, a detailed country analysis on the link between economic complexity and the ecological footprint would reveal specific factors and conditions that bring additional units to the 
ecological deficit, which would be beneficial for designing energy and economic policies with realistic targets that are meant to ensure sustainability (economic, environmental and social).

Funding: This research received no external funding.

Acknowledgments: I would like to express my gratitude to the anonymous referees for their valuable comments, which significantly improved the paper.

Conflicts of Interest: The author declares no conflict of interest.

\section{Appendix A}

Table A1. Countries included in the study.

\begin{tabular}{|c|c|c|}
\hline & Country & $\begin{array}{c}\text { Economic Complexity Index (ECI) } \\
\text { Average Values (1995-2014) }\end{array}$ \\
\hline 1 & Japan & 2.3289 \\
\hline 2 & Germany & 1.9954 \\
\hline 3 & Switzerland & 1.9851 \\
\hline 4 & Sweden & 1.8588 \\
\hline 5 & United Kingdom & 1.7551 \\
\hline 6 & Finland & 1.7152 \\
\hline 7 & Austria & 1.6579 \\
\hline 8 & USA & 1.6531 \\
\hline 9 & Singapore & 1.5258 \\
\hline 10 & France & 1.4897 \\
\hline 11 & Czech Rep. & 1.4476 \\
\hline 12 & Slovenia & 1.4268 \\
\hline 13 & Ireland & 1.3606 \\
\hline 14 & Italy & 1.3346 \\
\hline 15 & South Korea & 1.2535 \\
\hline 16 & Denmark & 1.2209 \\
\hline 17 & Slovakia & 1.1559 \\
\hline 18 & Netherlands & 1.1274 \\
\hline 19 & Hungary & 1.1016 \\
\hline 20 & Israel & 1.0358 \\
\hline 21 & Spain & 0.9657 \\
\hline 22 & Norway & 0.9167 \\
\hline 23 & Poland & 0.8265 \\
\hline 24 & Belarus & 0.8091 \\
\hline 25 & Canada & 0.7635 \\
\hline 26 & Mexico & 0.7474 \\
\hline 27 & Brazil & 0.7257 \\
\hline 28 & Croatia & 0.6280 \\
\hline 29 & Ukraine & 0.6325 \\
\hline 30 & Malaysia & 0.5762 \\
\hline 31 & Estonia & 0.5640 \\
\hline 32 & Russia & 0.5914 \\
\hline 33 & Romania & 0.5063 \\
\hline 34 & New Zealand & 0.4731 \\
\hline 35 & Portugal & 0.4648 \\
\hline 36 & Latvia & 0.4409 \\
\hline 37 & Argentina & 0.3802 \\
\hline 38 & Bulgaria & 0.3652 \\
\hline 39 & Lithuania & 0.3365 \\
\hline 40 & South Africa & 0.3202 \\
\hline 41 & Australia & 0.2645 \\
\hline 42 & Uruguay & 0.2451 \\
\hline 43 & Greece & 0.2499 \\
\hline 44 & Thailand & 0.1995 \\
\hline 45 & India & 0.2116 \\
\hline 46 & Turkey & 0.1896 \\
\hline 47 & Saudi Arabia & 0.1131 \\
\hline 48 & Colombia & 0.0241 \\
\hline
\end{tabular}

Source of data: [49]. 


\section{References}

1. Yusuf, A.M.; Abubakar, A.B.; Mamman, S. Relationship between greenhouse gas emission, energy consumption, and economic growth: Evidence from some selected oil-producing African countries. Environ. Sci. Pollut. Res. 2020, 27, 15815-15823. [CrossRef]

2. Gorus, M.S.; Aydin, M. The relationship between energy consumption, economic growth, and $\mathrm{CO}_{2}$ emission in MENA countries: Causality analysis in the frequency domain. Energy 2019, 168, 815-822. [CrossRef]

3. Muhamad, B. Energy consumption, $\mathrm{CO}_{2}$ emissions and economic growth in developed, emerging and Middle East and North Africa countries. Energy 2019, 179, 232-245. [CrossRef]

4. Acheampong, A.O. Economic growth, $\mathrm{CO}_{2}$ emissions and energy consumption: What causes what and where? Energy Econ. 2018, 74, 677-692. [CrossRef]

5. Wang, S.; Li, G.; Fang, C. Urbanization, economic growth, energy consumption, and $\mathrm{CO}_{2}$ emissions: Empirical evidence from countries with different income levels. Renew. Sustain. Energy Rev. 2018, 81, $2144-2159$. [CrossRef]

6. Antonakakis, N.; Chatziantoniou, I.; Filis, G. Energy consumption, $\mathrm{CO}_{2}$ emissions, and economic growth: An ethical dilemma. Renew. Sustain. Energy Rev. 2017, 68, 808-824. [CrossRef]

7. Zaman, K.; Moemen, M.A. Energy consumption, carbon dioxide emissions and economic development: Evaluating alternative and plausible environmental hypothesis for sustainable growth. Renew. Sustain. Energy Rev. 2017, 74, 1119-1130. [CrossRef]

8. Wang, S.; Li, Q.; Fang, C.; Zhou, C. The relationship between economic growth, energy consumption, and $\mathrm{CO}_{2}$ emissions: Empirical evidence from China. Sci. Total Environ. 2016, 542, 360-371. [CrossRef] [PubMed]

9. Mercan, M.; Karakaya, E. Energy consumption, economic growth and carbon emission: Dynamic panel cointegration analysis for selected OECD countries. Procedia Econ. Financ. 2015, 23, 587-592. [CrossRef]

10. Saidi, K.; Hammami, S. The impact of $\mathrm{CO}_{2}$ emissions and economic growth on energy consumption in 58 countries. Energy Rep. 2015, 1, 62-70. [CrossRef]

11. Alom, K. Economic Growth, $\mathrm{CO}_{2}$ Emissions and Energy Consumption: Evidence from Panel Data for South Asian Region. J. Knowl. Glob. 2014, 7, 37-55. Available online: http://www.journal.kglobal.org/index.php/ jkg/article/view/193 (accessed on 28 July 2020).

12. Salahuddin, M.; Gow, J. Economic growth, energy consumption and $\mathrm{CO}_{2}$ emissions in Gulf Cooperation Council countries. Energy 2014, 73, 44-58. [CrossRef]

13. Al-Mulali, U.; Lee, J.Y.; Mohammed, A.H.; Sheau-Ting, L. Examining the link between energy consumption, carbon dioxide emission, and economic growth in Latin America and the Caribbean. Renew. Sustain. Energy Rev. 2013, 26, 42-48. [CrossRef]

14. Ozcan, B. The nexus between Carbon emissions, energy consumption and economic growth in middle east countries: A panel data analysis. Energy Policy 2013, 62, 1138-1147. [CrossRef]

15. Saboori, B.; Sulaiman, J. $\mathrm{CO}_{2}$ emissions, energy consumption and economic growth in Association of Southeast Asian Nations (ASEAN) countries: A cointegration approach. Energy 2013, 55, 813-822. [CrossRef]

16. Arouri, M.E.H.; Ben Youssef, A.M.; Hatem, M.; Rault, C. Energy consumption, economic growth and $\mathrm{CO}_{2}$ emissions in Middle East and North African countries. Energy Policy 2012, 45, 342-349. [CrossRef]

17. Wang, S.S.; Zhou, D.Q.; Zhou, P.; Wang, Q.W. $\mathrm{CO}_{2}$ emissions, energy consumption and economic growth in China: A panel data analysis. Energy Policy 2011, 39, 4870-4875. [CrossRef]

18. Apergis, N.; Payne, J.E. The emissions, energy consumption, and growth nexus: Evidence from the commonwealth of independent states. Energy Policy 2010, 38, 650-655. [CrossRef]

19. Acaravci, A.; Ozturk, I. On the relationship between energy consumption, $\mathrm{CO}_{2}$ emissions and economic growth in Europe. Energy 2010, 35, 5412-5420. [CrossRef]

20. Narayan, P.K.; Narayan, S. Carbon dioxide emissions and economic growth: Panel data evidence from developing countries. Energy Policy 2010, 38, 661-666. [CrossRef]

21. Soytas, U.; Sari, R. Energy consumption, economic growth, and Carbon emissions: Challenges faced by an EU candidate member. Ecol. Econ. 2009, 68, 1667-1675. [CrossRef]

22. Soytas, U.; Sari, R.; Ewing, B.T. Energy consumption, income, and Carbon emissions in the United States. Ecol. Econ. 2007, 62, 482-489. [CrossRef]

23. Vaheed, R.; Sarwar, S.; Wei, C. The survey of economic growth, energy consumption and carbon emissions. Energy Rep. 2019, 5, 1103-1115. [CrossRef] 
24. Shahbaz, M.; Mahalik, M.K.; Shah, S.H.; Sato, J.R. Time-varying analysis of $\mathrm{CO}_{2}$ emissions, energy consumption, and economic growth nexus: Statistical experience in next 11 countries. Energy Policy 2016, 98, 33-48. [CrossRef]

25. Ahmed, Z.; Wang, Z.; Mahmood, F.; Hafeez, M.; Ali, N. Does globalization increase the ecological footprint? Empirical evidence from Malaysia. Environ. Sci. Pollut. Res. 2019, 26, 18565-18582. [CrossRef]

26. Destek, M.A.; Ulucak, R.; Dogan, E. Analyzing the environmental Kuznets curve for the EU countries: The role of ecological footprint. Environ. Sci. Pollut. Res. 2018, 25, 29387-29396. [CrossRef]

27. Charfeddine, L. The impact of energy consumption and economic development on ecological footprint and $\mathrm{CO}_{2}$ emissions: Evidence from a markov switching equilibrium correction model. Energy Econ. 2017, 65, 355-374. [CrossRef]

28. Mrabet, Z.; Alsamara, M. Testing the Kuznets curve hypothesis for Qatar: A comparison between carbon dioxide and ecological footprint. Renew. Sustain. Energy Rev. 2017, 70, 1366-1375. [CrossRef]

29. Ozturk, I.; Al-Mulali, U.; Saboori, B. Investigating the environmental Kuznets curve hypothesis: The role of tourism and ecological footprint. Environ. Sci. Pollut. Res. 2016, 23, 1916-1928. [CrossRef]

30. Al-Mulali, U.; Weng-Wai, C.; Sheau-Ting, L.; Mohammed, A.H. Investigating the environmental Kuznets curve (EKC) hypothesis by utilizing the ecological footprint as an indicator of environmental degradation. Ecol. Indic. 2015, 48, 315-323. [CrossRef]

31. Galli, A.; Kitzes, J.; Niccolucci, V.; Wackernagel, M.; Wada, Y.; Marchettini, N. Assessing the global environmental consequences of economic growth through the ecological footprint: A focus on China and India. Ecol. Indic. 2012, 17, 99-107. [CrossRef]

32. Bagliani, M.; Bravo, G.; Dalmazzone, S. A consumption-based approach to environmental Kuznets curves using the ecological footprint indicator. Ecol. Econ. 2008, 65, 650-661. [CrossRef]

33. Lin, D.; Hanscom, L.; Martindill, J.; Borucke, M.; Cohen, L.; Galli, A.; Lazarus, E.; Zokai, G.; Iha, K.; Eaton, D.; et al. Working Guidebook to the National Footprint and Biocapacity Accounts; Global Footprint Network: Oakland, CA, USA, 2019; Available online: http://www.footprintnetwork.org/ (accessed on 5 July 2020).

34. Global Footprint Network. Available online: http://data.footprintnetwork.org (accessed on 4 July 2020).

35. Altintaş, H.; Kassouri, Y. Is the environmental Kuznets curve in Europe related to the per-capita ecological footprint or $\mathrm{CO}_{2}$ emissions? Ecol. Indic. 2020, 113, 106187. [CrossRef]

36. Dogan, E.; Ulucak, R.; Kocak, E.; Isik, C. The use of ecological footprint in estimating the environmental Kuznets curve hypothesis for BRICST by considering cross-section dependence and heterogeneity. Sci. Total Environ. 2020, 138063. [CrossRef]

37. Alola, A.A.; Bekun, F.V.; Sarkodie, S.A. Dynamic impact of trade policy, economic growth, fertility rate, renewable and nonrenewable energy consumption on ecological footprint in Europe. Sci. Total Environ. 2019, 685, 702-709. [CrossRef]

38. Chen, S.; Saud, S.; Saleem, N.; Bari, M.W. Nexus between financial development, energy consumption, income level, and ecological footprint in CEE countries: Do human capital and biocapacity matter? Environ. Sci. Pollut. Res. 2019, 26, 31856-31872. [CrossRef]

39. Destek, M.A.; Sarkodie, S.A. Investigation of environmental Kuznets curve for ecological footprint: The role of energy and financial development. Sci. Total Environ. 2019, 650, 2483-2489. [CrossRef]

40. Danish; Hassan, S.T.; Baloch, M.A.; Mahmood, N.; Zhang, J.W. Linking economic growth and ecological footprint through human capital and biocapacity. Sustain. Cities Soc. 2019, 47, 101516. [CrossRef]

41. Ulucak, R.; Bilgili, F. A reinvestigation of EKC model by ecological footprint measurement for high, middle and low income countries. J. Clean. Prod. 2018, 188, 144-157. [CrossRef]

42. Ozcan, B.; Apergis, N.; Shahbaz, M. A revisit of the environmental Kuznets curve hypothesis for Turkey: New evidence from bootsrap rolling window causality. Environ. Sci. Pollut. Res. 2018, 25, 32381-32394. [CrossRef] [PubMed]

43. Charfeddine, L.; Mrabet, Z. The impact of economic development and social-political factors on ecological footprint: A panel data analysis for 15 MENA countries. Renew. Sustain. Energy Rev. 2017, 76, 138-154. [CrossRef]

44. Uddin, G.A.; Salahuddin, M.; Alam, K.; Gow, J. Ecological footprint and real income: Panel data evidence from the 27 highest emitting countries. Ecol. Indic. 2017, 77, 166-175. [CrossRef]

45. Aşıc1, A.A.; Acar, S. Does income growth relocate ecological footprint? Ecol. Indic. 2016, 61, 707-714. [CrossRef]

46. Hausmann, R.; Hidalgo, C.A.; Bustos, S.; Coscia, M.; Simoes, A.; Yildirim, M.A. The Atlas of Economic Complexity: Mapping Paths to Prosperity; MIT Press: Cambridge, MA, USA, 2014; Available online: https://s3.amazonaws. 
com/academia.edu.documents/30678659/HarvardMIT_AtlasOfEconomicComplexity_Part_I.pdf?A (accessed on 3 August 2020).

47. Can, M.; Gozgor, G. The impact of economic complexity on carbon emissions: Evidence from France. Environ. Sci. Pollut. Res. 2017, 24, 16364-16370. [CrossRef]

48. Neagu, O.; Teodoru, M.C. The relationship between economic complexity, energy consumption structure and greenhouse gas emission: Heterogeneous panel evidence from the EU countries. Sustainability 2019, 11, 497. [CrossRef]

49. Atlas of Economic Complexity. Available online: https://atlas.cid.harvard.edu/countries/ (accessed on 20 July 2020).

50. Swart, J.; Brinkman, L. Economic Complexity and the Environment: Evidence from Brazil. In Universities and Sustainable Communities: Meeting the Goals of the Agenda 2030; Leal, W., Tortato, U., Frankenberger, F., Eds.; World Sustainability Series; Springer Nature: Heidelberg, Germany, 2020; pp. 3-45. [CrossRef]

51. Yilanci, V.; Pata, U.K. Investigating the EKC hypothesis for China: The role of economic complexity on ecological footprint. Environ. Sci. Pollut. Res. 2020, 27, 32683-32694. [CrossRef] [PubMed]

52. Pata, U.K. Renewable and non-renewable energy consumption, economic complexity, $\mathrm{CO}_{2}$ emissions, and ecological footprint in the USA: Testing the EKC hypothesis with a structural break. Environ. Sci. Pollut. Res. 2020, 1-16. [CrossRef]

53. Shahzad, U.; Fareed, Z.; Shahzad, F.; Shahzad, K. Investigating the nexus between economic complexity and ecological footprint for the United States: New insights from quantile methods. J. Clean. Prod. 2020, 279, 123806. [CrossRef]

54. Ansari, M.A.; Haider, S.; Khan, N.A. Environmental Kuznets curve revisited: An analysis using ecological and material footprint. Ecol. Indicat. 2020, 115, 106416. [CrossRef]

55. Baz, K.; Xu, D.; Ali, H.; Ali, I.; Khan, I.; Khan, M.M.; Cheng, J. Asymmetric impact of energy consumption and economic growth on ecological footprint: Using asymmetric and nonlinear approach. Sci. Total Environ. 2020, 718, 137364. [CrossRef]

56. Caviglia-Harris, J.L.; Chambers, D.; Kahn, J.R. Taking the "U" out of Kuznets: A comprehensive analysis of the EKC and environmental degradation. Ecol. Econ. 2009, 68, 1149-1159. [CrossRef]

57. Chen, C.Z.; Lin, Z.S. Multiple timescale analysis and factor analysis of energy ecological footprint growth in China 1953-2006. Energy Policy 2008, 36, 1666-1678. [CrossRef]

58. Chen, B.; Chen, G.Q. Modified ecological footprint accounting and analysis based on embodied exergy: A case study of the Chinese society 1981-2001. Ecol. Econ. 2007, 61, 355-376. [CrossRef]

59. Chen, B.; Chen, G.Q.; Yang, Z.F.; Jiang, M.M. Ecological footprint accounting for energy and resource in China. Energy Policy 2007, 35, 1599-1609. [CrossRef]

60. Danish; Ulucak, R.; Khan, S.U.-D. Determinants of the ecological footporint: Role of renewable energy, natural resources, and urbanization. Sustain. Cities Soc. 2020, 54, 101996. [CrossRef]

61. Sharif, A.; Baris-Tuzemen, O.; Uzuner, G.; Ozturk, I.; Sinha, A. Revisiting the role of renewable energy and non-renewable energy consumption on Turkey's ecological footprint: Evidence from Quantile ARDL approach. Sustain. Cities Soc. 2020, 57, 102138. [CrossRef]

62. Destek, M.A.; Sinha, A. Renewable, non-renewable enegy consumption, economic growth, trade openess and ecological footprint: Evidence from organisation for economic cooperation and development countries. J. Clean. Prod. 2020, 242, 118537. [CrossRef]

63. Bello, M.O.; Solarin, S.A.; Yen, Y.Y. The impact of electricity consumption on $\mathrm{CO}_{2}$ emission, carbon footprint, water footprint and ecological footprint: The role of hydropower in an emerging economy. J. Environ. Manag. 2018, 219, 218-230. [CrossRef]

64. Udemba, E.N. A sustainable study of economic growth and development amidst Ecological Footprint. Sci. Total Environ. 2020, 732, 139270. [CrossRef]

65. Ahmed, Z.; Zafar, M.W.; Ali, S.; Danish, K. Linking urbanization, human capital, and the ecological footprint in G7 countries: An empirical analysis. Sustain. Cities Soc. 2020, 55, 102064. [CrossRef]

66. Majid, M.R.; Zaman, M.; Halim, N. Gis-Based Regression Analysis of the Relationship between Ecological Footprint and Economic Development of Selected Countries. Plan. Malaysia 2018, 16, 221-232. Available online: http://planningmalaysia.org/index.php/pmj/article/view/513 (accessed on 10 July 2020). [CrossRef]

67. Mrabet, Z.; Alsamara, M.; Jarallah, S.H. The impact of economic development on environmental degradation in Qatar. Environ. Ecol. Stat. 2016, 24, 7-38. [CrossRef] 
68. Destek, M.A.; Okumus, I. Does pollution have hypothesis hold in newly industrialized countries? Evidence from ecological footprint. Environ. Sci. Pollut. Res. 2019, 26, 23689-23695. [CrossRef]

69. Zafar, M.W.; Zaidi, S.A.H.; Khan, N.R.; Mirza, F.M.; Hou, F.; Kirmani, S.A.A. The impact of natural resources, human capital, and foreign direct investment on the ecological footprint: The case of Unites States. Resour. Policy 2019, 63, 101428. [CrossRef]

70. Usman, M.; Kousar, R.; Yaseen, M.R.; Makhdum, M.S.A. An empirical nexus between economic growth, energy utilization, trade policy, and ecological footprint: A continent-wise comparison in upper-middle-income countries. Environ. Sci. Pollut. Res. 2020, 27, 38995-39018. [CrossRef]

71. Wang, J.; Dong, K. What drives environmental degradation? Evidence from 14 Sub-Saharan African countries. Sci. Total Environ. 2019, 656, 165-173. [CrossRef]

72. Sarkodie, S.A. The invisible hand and EKC hypothesis: What are the drivers of environmental degradation and pollution in Africa? Environ. Sci. Pollut. Res. 2018, 25, 21993-22022. [CrossRef] [PubMed]

73. Uddin, G.A.; Alam, K.; Gow, J. Ecological and economic growth interdependency in the asian economies: An empirical analysis. Environ. Sci. Pollut. Res. 2019, 26, 13159-13172. [CrossRef] [PubMed]

74. Dogan, B.; Saboori, B.; Can, M. Does economic complexity matter for environmental degradation? An empirical analysis for different stages of development. Environ. Sci. Pollut. Res. 2019, 26, 31900-31912. [CrossRef]

75. Lapatinas, A.; Garas, A.; Boleti, E.; Kyriakou, A. Economic Complexity and Environmental Performance: Evidence from a World Sample; MPRA Paper No. 92833. 2019. Available online: https://mpra.ub.unimuenchen.de/92833/ (accessed on 15 July 2020).

76. Chu, L.K. Economic structure and environmental Kuznets curve hypothesis: New evidence from economic complexity. Appl. Econ. Lett. 2020, 1-5. [CrossRef]

77. Hidalgo, C.A.; Hausmann, R. The building blocks of economic complexity. Proc. Natl. Acad. Sci. USA 2009, 106, 10570-10575. [CrossRef] [PubMed]

78. World Bank. World Development Indicators Online Database. 2020. Available online: https://databank. worldbank.org/source/world-developmentindicators (accessed on 10 July 2020).

79. Pesaran, M.H. General Diagnostic Tests for Cross Section Dependence in Panels; Cambridge Working Papers in Economics No. 0435; University of Cambridge, Faculty of Economics: Cambridge, MA, USA, 2004; Available online: https://www.repository.cam.ac.uk/handle/1810/446 (accessed on 2 August 2020).

80. Phillips, P.; Sul, D. Dynamic panel estimation and homogeneity testing under cross-section dependence. Econ. J. 2003, 6, 217-259. [CrossRef]

81. Pesaran, M.H. A simple panel unit root test in the presence of cross-section dependence. J. Appl. Econom. 2007, 22, 265-312. [CrossRef]

82. Eggoh, J.C.; Bangake, C.; Rault, C. Energy consumption and economic growth revisited in African countries. J. Appl. Econ. 2007, 22, 265-312. [CrossRef]

83. Dogan, E.; Seker, F. An investigation on the determinants of carbon emissions for OECD countries: Empirical evidence from panel models robust to heterogeneity and cross-sectional dependence. Environ. Sci. Pollut. Res. 2016, 23, 14646-14655. [CrossRef] [PubMed]

84. Asafu-Adjaye, J.; Byrne, D.; Alvarez, M. Economic growth, fossil fuel, and non fossil consumption: A Pooled Mean Group analysis using proxies for capital. Energy Econ. 2016, 60, 345-356. [CrossRef]

85. Dogan, E.; Aslan, A. Exploring the relationship among $\mathrm{CO}_{2}$ emissions, real GDP, energy consumption and tourism in the EU and candidate countries: Evidence from panel models robust to heterogeneity and cross-sectional dependence. Renew. Sustain. Energy Rev. 2017, 77, 239-245. [CrossRef]

86. Jardon, A.; Kuik, O.; Tol, R.S.J. Economic growth and carbon dioxide emissions: An analysis of Latin America and the Caribbean. Atmosfera 2017, 30, 87-100. [CrossRef]

87. Mensah, I.A.; Sun, M.; Gao, C.; Omari-Sasu, A.Y.; Zhu, D.; Ampimah, B.C.; Quarcoo, A. Analysis of the nexus of economic growth, fossil fuel energy consumption, $\mathrm{CO}_{2}$ emissions and oil price in Africa based on PMG panel ARDL approach. J. Clean. Prod. 2019, 228, 161-174. [CrossRef]

88. Engle, R.F.; Granger, C.W.J. Co-integration and Error Correction: Representation, Estimation, and Testing. Econometrica 1987, 55, 251. [CrossRef]

89. Pedroni, P. Critical Values for Cointegration Tests in Heterogeneous Panels with Multiple Regressors. Oxf. Bull. Econ. Stat. 1999, 61, 653-670. [CrossRef] 
90. Pedroni, P. Panel cointegration: Asymptotic and finite sample properties of pooled time series tests with an application to the PPP hypothesis. Econ. Theory 2004, 20, 597-625. [CrossRef]

91. Westerlund, J. New simple tests for panel cointegration. Econ. Rev. 2005, 24, 297-316. [CrossRef]

92. Pedroni, P. Fully Modified OLS for Heterogeneous Cointegrated Panels. In Advances in Econometrics; Badi, H., Thomas, B.B., Fomby, R., Hill, C., Eds.; Nonstationary Panels, Panel Cointegration and Dynamic Panels; Emerald Group Publishing Limited: Bingley, UK, 2001; Volume 15, pp. 93-130. Available online: https://www.emeraldinsight.com/doi/abs/10.1016/S0731-9053(00)15004-2 (accessed on 12 July 2020).

93. Pedroni, P. Purchasing Power Parity Tests in Cointegrated Panels. Rev. Econ. Stat. 2001, 83, 727-731. Available online: https://EconPapers.repec.org/RePEc:wil:wileco:2001-01 (accessed on 12 July 2020). [CrossRef]

94. Hausmann, R.; Hwang, J.; Rodrik, D. What you export matters. J. Econ. Growth 2006, 12, 1-25. [CrossRef]

95. Hidalgo, C.A.; Klinger, B.; Barabasi, A.L.; Hausmann, R. The product space conditions the development of nations. Science 2007, 317, 482-487. [CrossRef] [PubMed]

96. Hausmann, R.; Hidalgo, C.A. The network structure of economic output. J. Econ. Growth 2011, 16, $309-342$. [CrossRef]

97. Felipe, J.; Kumar, U.; Abdon, A.; Bacate, M. Product complexity and economic development. Struct. Chang. Econ. Dyn. 2012, 23, 36-68. [CrossRef]

98. Neagu, O. The link between economic complexity and carbon emissions in the European Union countries. A model based on the Environmental Kuznets Curve (EKC) approach. Sustainability 2019, 11, 4753. [CrossRef]

99. Dong, Z.; Chen, W.; Wang, S. Emission reduction target, complexity and industrial performance. J. Environ. Manag. 2020, 260, 110148. [CrossRef]

100. Romero, J.P.; Gramkow, C. Economic Complexity and Greenhouse Gas Emisssion Intensity; Cambridge Centre for Economic and Public Policy, Department of Land Economy, CCEPP WPO3, University of Cambridge: Cambridge, MA, USA, 2020; Available online: https://oec.world/en/resources/library (accessed on 12 October 2020).

101. Intergovernmental Panel on Climate Change (IPCC). 2017. Available online: https://www.ipcc.ch/ (accessed on 1 July 2020).

102. IEA. Available online: https://www.iea.org/countries/ (accessed on 30 August 2020).

Publisher's Note: MDPI stays neutral with regard to jurisdictional claims in published maps and institutional affiliations.

(C) 2020 by the author. Licensee MDPI, Basel, Switzerland. This article is an open access article distributed under the terms and conditions of the Creative Commons Attribution (CC BY) license (http://creativecommons.org/licenses/by/4.0/). 